\section{Tobacco: Incessant Human Health Menace (A Review)}

\section{Abstract}

Tobacco plant, the most sought after weed in the world, having its roots in America has already made its appearance felt worldwide along the course of time. Regarded as a medicinal herb in the beginning, now it is held responsible for enormous sufferings and countless ailments affecting almost every system of human body. Tobacco is consumed either by smoking or chewing (smokeless). It is thought to have soothing effects on the consumer thereby making him a habitué. Nicotine, the main component present in tobacco, causes the release of neurotransmitters from the brain thereby, brings the good effect on the body and mind of the individual. But it is a temporary feeling and the person is actually pushing himself to a never ending addiction and life taking diseases including cardiovascular and pulmonary ailments. According to WHO, globally, coronary heart diseases result in around 7.3 million death annually, along with respiratory diseases (3.1 million) and lung cancers (1.6 million). Other worth mentioning health problem is the oral cancer which is very common in Indian population due to widespread habit of chewing tobacco. WHO estimates that India ranks $1^{\text {st }}$ globally in death tally due to oral cancers. The health hazards due to tobacco consumption are escalating and there's an urgent need to address this issue. Efforts are already being done in the form of advertisements to avoid tobacco but had they been enough, results would have been different. No doubt treatments are available but there are risks, therefore, other programs like cessation and de-addiction need to be promoted. People should be made aware of the consequences and efforts have to be made at local and global level. This review is a step to create awareness regarding tobacco health hazards and how they are being dealt with.

Keywords: Tobacco; Coronary diseases; Lung cancer; Oral cancer; Nicotine; Smoking; De-addiction

\section{Manju Kaundal ${ }^{1}$ and Bhopesh Thakur $^{2}$}

\author{
1 IsharJyot Degree College, Pehowa, \\ Kurukshetra, Haryana, India \\ 2 University College, Kurukshetra \\ University, Kurukshetra, Haryana, India
}

Corresponding author: Manju Kaundal

\section{kaundalm@gmail.com}

Department of Zoology, IsharJyot Degree College, Pehowa, Haryana, India.

Tel: 8295959669

Citation: Kaundal M, Thakur B. Tobacco: Incessant Human Health Menace (A Review). J Drug Abuse. 2015, 1:1.

Received: November 14, 2015; Accepted: December 01, 2015; Published: December 08,2015

\section{History}

Initially, Tobacco was grown in America in 6000 BC. There is no written record in reference to tobacco prior to the $15^{\text {th }}$ century. However, it is generally acknowledged that indigenous Americans used tobacco as a medicine and smoked tobacco. In 1492, Christopher Columbus (1451-1506) and his crew, when returning to Europe from America, brought the first tobacco leaves and seeds into Europe. In 1560, Jean Nicot (1530-1600), French diplomat and importer, introduced tobacco in France and Portugal. By the end of the $16^{\text {th }}$ century, tobacco use had become a custom among fashionable people in Europe, and tobacco was being exported to India, China and Japan [1, 2]. It was used as country money and given as pay throughout $17^{\text {th }}$ and $18^{\text {th }}$ centuries in Europe. It was regarded as a medicinal herb in the beginning and used for the treatment of various ailments, viz., colic, nephritis, hysteria, hernia, dysentery, toothache, falling fingernails, worms, halitosis, lockjaw and cancer [3]. Suddenly, this medicinal herb transformed in to a violent herb, as first evidence of its harmful effect on human health came to light in 1791, when Snuff (powdered tobacco breathed through nose) was associated with nasal cancer, and in 1795, pipe smoking was found to cause lip cancer. Since then the list of deleterious effects of tobacco is unending. 


\section{Introduction}

Tobacco is a product processed from the dried leaves of plants of the genus Nicotiana (Family Solanaceae or commonly known as nightshade family). Tobacco smoke is a complex, dynamic and reactive mixture containing an estimated 5,000 chemicals [4-6]. This toxic and carcinogenic mixture is probably the most significant source of toxic chemical exposure and chemically mediated diseases in humans $[7,8]$. Cancers figure among the leading causes of morbidity and mortality worldwide, with approximately 14 million new cases and 8.2 million cancer related deaths in 2012 (WHO Report, 2014). The number of new cases is expected to rise by about $70 \%$ over the next two decades. Tobacco use is the most important risk factor for cancer causing around $20 \%$ of global cancer deaths and around $70 \%$ of global lung cancer deaths. More than $60 \%$ of world's total new annual cases occur in Africa, Asia and Central and South America. These regions account for $70 \%$ of the world's cancer deaths (WHO Report, 2014). Therefore, present review is composed with an idea to collect the widely spread information in relation to tobacco, it's constituents, diverse health hazards, it's diagnosis, treatment, cessation and de-addiction, at a single place.

\section{Components of Tobacco}

\section{Nicotine}

This is the addictive component of tobacco. It is absorbed into the blood and affects the brain within 10 seconds. It causes smokers to feel good because of the neurotransmitters that it releases. It also causes a surge of heart rate, blood pressure and adrenaline.

\section{Tar}

It is a thick, sticky substance, and when inhaled it sticks to the tiny hairs on the lungs, i.e., cilia, which normally protect the lungs from dirt and infection, but when covered in tar they are unable to perform their function. Tar coats the walls of the whole respiratory system, narrowing the bronchioles that transport air and also reduce elasticity of the lungs.

\section{Carbon monoxide}

A poisonous chemical which competes with oxygen for haemoglobin of blood and hence decreases the amount of oxygen in the blood, thus depriving all the organs of oxygen. Due to less oxygen in the blood, it gets thicker and puts a strain on the heart to pump. In addition to these, tobacco in cigarette smoke contains a large number of recognized carcinogens and mutagens, such as radioactive Polonium, Benzopyrine, Dimethylbenzanthracene, Dimethylnitrosamine, Naphthaene, Methylnaphthalene, Benzene, Formaldehyde, Ammonia, Hydrogen cyanide, Cadmium, Acetone and Arsenic (Table 1).

According to WHO, every year around 56 million people die worldwide due to various ailments with coronary heart diseases (7.3 million), lung diseases (3.1 million) and lung cancer ( 1.6 million), topping the list and contribution of tobacco smoking to this overall death toll is most prominent. India, the second most populous country in the world, ranks $1^{\text {st }}$ in lung cancer predominance and $9^{\text {th }}$ in oral cancer, globally. It was decided to study the past and present tobacco health hazards in this country, as a part of this review.

\section{Indian Scenario}

The gateway for entry of the tobacco in to India was Goa in 1605, by the Portuguese. It was used as barter for cotton and other things. Today, India is the second largest consumer of tobacco products in the world, in spite of the advances in public health campaigns complemented with tobacco control laws. Nearly 900, 000 people die every year in India due to the diseases attributed to tobacco. Reports from the World Health Organisation, predicts that deaths in India due to tobacco may exceed 1.5 million annually by 2020 [9].

India has a confounding variety of tobacco use, as a result of which, it faces diverse epidemics which differ by geography, population, gender, age, socioeconomic status and educational attainment. The smoking habits in India vary to a large extent from cigarettes, cigar, bidi, chillum, hukka, etc. [10]. The cheapest of smoking materials, largely consumed is bidi [11, 12]. It consists of 0.2-0.3 grams of tobacco wrapped in Tendu leaf and was considered less harmful earlier. But later it was found that, bidis have higher levels of toxic substances like tar, nicotine, hydrogen cyanide, benzopyrene, etc. Contrary to cigarette packs, bidi bundles are tax free and do not have the statutory warning.

According to the Global Adult Tobacco Survey [13], the prevalence of tobacco use among males in India is $48 \%$ compared with $20 \%$ among females. It is estimated that more than one-third (35\%) of adults in India use tobacco in some form or the other. The number of tobacco users in India exceeds the population of Indonesia and Canada, if combined by itself this number would be equivalent to the fourth largest country in the world. (Table 2 )

In India, lung cancer grew rapidly between 1950 and 1959, and doubled between 1954 and 1957; hence this period potentially noticed the manifestation of the negative impact of smoking in India. Earlier studies incriminated bidi smoking with higher risk of cancer and established that smoking bidis is no less hazardous than cigarettes.

Tobacco smoking in most parts of India except Punjab, Maharashtra and Sikkim is reported in about one fourth to half of adult men of over 15 years of age. In the North East and southern regions of India, cigarette smoking is more prevalent than bidi smoking. Amongst women, smoking is more common in the North Eastern states, Jammu and Kashmir and Bihar, while most other parts of India had prevalence rates of about 4 per cent or less. Bidi, is the most common smoking product especially in the rural population and there, even women have no inhibitions regarding bidi smoking. Hookah smoking, the more traditional way in which tobacco is kept in an earthen pot (chillum) along with the burning coal and smoked through a water container with the help of a long pipe was present in about $6 \%$ of rural and less than $1 \%$ of urban smokers. On an average the number of cigarettes or bidis smoked daily was similar in both rural (15.0 \pm 17.0) and urban (12.4 \pm 10.7$)$ areas.

Tobacco habits are much ingrained into society as much as food and dress habits. Over the past 60 years, a number of studies 
Table 1. Effects of tobacco smoke on human health.

\begin{tabular}{|c|c|c|c|}
\hline 1. & General & Addiction & Strong urges to smoke, anxious or irritable feeling $[30,31]$. \\
\hline \multirow[b]{2}{*}{2.} & \multirow[b]{2}{*}{ Brain } & Stress & Higher in smokers [32] \\
\hline & & Brain chemistry & $\begin{array}{l}\text { Initial increase in dopamine activity; Subsequent fewer dopamine receptors [33]. } \\
\text { Dopamine gives a sense of reward and pleasant feelings [34], Craving more for cigarettes [35, 36]. }\end{array}$ \\
\hline \multirow{4}{*}{3.} & \multirow{4}{*}{ Respiratory System } & Bronchospasm & Airway irritability. Susceptible to asthma. \\
\hline & & Phlegm production & Higher goblet cell growth. Mucus collection in the lungs [37]. \\
\hline & & Persistent cough & \\
\hline & & Decreased physical & performance \\
\hline \multirow{7}{*}{4.} & \multirow{7}{*}{ Cardiovascular System } & $\begin{array}{l}\text { Adverse lipid } \\
\text { profile }\end{array}$ & $\begin{array}{l}\text { Amount of bad fats (LDL, triglycerides, cholesterol) increases; Amount of good fat (HDL) } \\
\text { decreases [38]. } \\
\text { Narrowing of blood vessels; impaired blood flow to the heart, brain and other organs, causing } \\
\text { them to fail. }\end{array}$ \\
\hline & & $\begin{array}{l}\text { Constriction of } \\
\text { blood vessels } \\
\text { (vasoconstriction) }\end{array}$ & $\begin{array}{l}\text { Decreased nitric oxide }\left(\mathrm{NO}_{2}\right) \text {; increased endothelin-1 (ET-1). } \\
\text { Increased risk of stroke or heart attack }[39,40] .\end{array}$ \\
\hline & & Thrombosis & $\begin{array}{l}\text { Blockage of blood vessels, stopping blood flow to vital organs. } \\
\text { More heart attacks; sudden death }[38,41] \text {. }\end{array}$ \\
\hline & & Atherosclerosis & $\begin{array}{l}\text { Fat and cholesterol form "plaques" and stick to the artery walls. } \\
\text { Reduction in blood flow through the artery [38]. }\end{array}$ \\
\hline & & $\begin{array}{l}\text { Increased heart } \\
\text { rate }\end{array}$ & $\begin{array}{l}\text { As soon as } 30 \text { minutes after puffing }[42,43] \\
\text { Early heart attack or stroke. }\end{array}$ \\
\hline & & $\begin{array}{l}\text { Increased blood } \\
\text { pressure }\end{array}$ & $\begin{array}{l}\text { Heart pumps harder [42-45]. } \\
\text { Heart and kidney damage. }\end{array}$ \\
\hline & & $\begin{array}{l}\text { Destabilize red } \\
\text { blood cells }\end{array}$ & $\begin{array}{l}\text { High levels of free radicals and lipid peroxidation [46]; loss of glutathione; formation of } \\
\text { Methaemoglobin; folate levels in serum [47]. } \\
\text { Cell haemolysis; Membrane loses its stability; oxidative stress. }\end{array}$ \\
\hline \multirow{5}{*}{5.} & \multirow{5}{*}{ Digestive System } & $\begin{array}{l}\text { Gastro- } \\
\text { oesophageal reflux } \\
\text { disease }\end{array}$ & $\begin{array}{l}\text { Intermittent loosening of the muscle sphincter separating the oesophagus and stomach; less } \\
\text { neutralization of acid by base. Heartburn [48] and acid regurgitation from the stomach [49]; } \\
\text { ulcerations of the lower oesophagus [50]. }\end{array}$ \\
\hline & & $\begin{array}{l}\text { Peptic ulcer } \\
\text { disease }\end{array}$ & $\begin{array}{l}\text { Excess acid is produced [51]; Mucous production in the stomach is inhibited [52]. } \\
\text { Self-digested holes extending into the muscular layers of the oesophagus, stomach, and a portion } \\
\text { of the small intestine [53]. }\end{array}$ \\
\hline & & $\begin{array}{l}\text { Periodontal } \\
\text { diseases }\end{array}$ & $\begin{array}{l}\text { Changes the blood supply, immune response, and healing mechanisms of the mouth. } \\
\text { Bacterial infections [54]; gum inflammation and tooth decay [48]; tooth and bone loss and } \\
\text { hastens deep gum pocket formation [55]. }\end{array}$ \\
\hline & & Halitosis & Bad breath, smelly hair and clothes, and yellow teeth [56]. \\
\hline & & Oral cancer & $\begin{array}{l}\text { Interaction between cigarette smoke and saliva may be deleterious; destruction of biological } \\
\text { macromolecules (enzymes and proteins) [57-60]. }\end{array}$ \\
\hline
\end{tabular}

6. Immune System

Increases total leucocytes (WBC) count, decreases CD4/CD8 T-cell ratio, decreases serum immunoglobulin levels and suppresses natural killer cell activity.

Disrupts the normal clearing mechanism of the ear canal, facilitating infectious organism entry into the body. Middle ear infection; hearing loss [61].

7. Otitis Media Slows or no ciliary movement of sinuses [62]. Inflammation and infection [48,63]; headaches, facial pain, tenderness, swelling, fever, cough, runny nose, sore throat, bad breath, and a decreased sense of smell.

8. Sinusitis

Rhinitis (inflammation

9. of the inner lining of the nasal passages)

Pneumonia

10. (inflammation of the lining of the lungs)

11. Female Reproductive Sneezing, congestion, runny nose, and itchy eyes, ears, and nose [64]. Sleep disturbances, activity limitations, irritability, moodiness, and decreased school performance [64].

Fluid accumulates deep in the lung, making it an ideal region for bacterial growth. Persistent cough and difficulty breathing; if left untreated, can lead to pus pocket formation, lung collapse, blood infection, and severe chest pain [53].

Deleterious effects on menstrual cycle; tubal function and embryo transport; control of oocyte production and viability; age of onset of menopause; and bone metabolism. Risk of arterial disease; low fertility and miscarriage; egg production, the fertilization process, embryo attachment, and the proper growth and development of the baby during the pregnancy; breast carcinogenesis [17].

Absorption of vitamins C, E and folic acid. Scurvy; Weakness, depression, inflamed gums, poor wound healing, and uncontrolled bleeding [53]. Vitamin E deficiency may cause blood breakdown, eye disease, and irreversible nerve problems of the hands, feet, and spinal cord. Folic acid deficiency may result in long-lasting anaemia, diarrhoea, and tongue swelling.

Scurvy and other

12. Micronutrient Disorders 
Table 2. Prevalence of tobacco in Indian population [65].

\begin{tabular}{|c|c|c|c|}
\hline Tobacco & $\begin{array}{c}\text { Total Adults } \\
\text { (in million) }\end{array}$ & Males (in million) & Females (in million) \\
\hline In any form & 111.2 & 99.9 & 11.3 \\
\hline Cigarette & 46.4 & 43.1 & 3.3 \\
\hline Bidi & 73.3 & 66.1 & 7.2 \\
\hline
\end{tabular}

have shown a significant relationship between tobacco smoking, especially cigarette smoking and development of lung cancer. Roughly speaking, smoking 10 cigarettes a day increases the risk of lung cancer 10 times.

\section{Targets of Cancer Diagnosis: Molecular Basis}

Tobacco related cancers result from the culmination of multiple genetic events including activation of oncogenes, inactivation of tumour suppressing genes, deregulation of gene involved in genetic instability, DNA damage repair, angiogenesis and neovascularisation, telomerase activity, failure of apoptosis, invasion and metastasis. Major thrust of research is on early diagnosis of the disease which can be achieved by identifying molecular markers for screening of high risk lesions and early intervention for prevention of transition to malignancy.

Tumour suppressor gene $\mathrm{p} 53$ has been proposed to play a pivotal role in the genesis of oral cancer. The immune-histochemical detection of p53 in biopsy specimens is of immense interest to an Oncopathologist as a potential tumour marker since $\mathrm{p} 53$ gene is frequently found to be mutated in a wide range of human malignancies resulting in p53 protein accumulation in tumour cells [14]. In a case of oral cancer, alterations are observed in the expression of cell cycle regulatory proteins, viz. p53, MDM2, p21, p16 and pRb. The levels of gene p53 and MDM2 are over expressed in a subset of lesions whereas loss of expression is observed for tumour suppressor genes p16 and pRb. Heinzel et al. [15] have shown that betel quid constituents, also act as carcinogens, p53 and p16 being the gene targets of mutations, leading to development of oral cancer.

Gene chip technology also shows great promise for providing mass screening of a large number of genetic factors. It involves attaching DNA probe for thousands of different gene sequences to a microchip. This microarray is then exposed to an individual tumour sample which has been labelled with a fluorescent tag and the relative amount of each gene transcript present in the tumour determined. The results of such a test helps to build a molecular profile of gene expression, in each tumour and to compare it with previously characterized tumour sample [16-18].

Chemo-prevention is a promising therapy which utilizes the administration of agents to block or reverse the process of tumourigenesis [19]. Retinoids are the functional analogues of vitamin A, which are potent chemo-preventive agents, and act as signalling molecule in the modulation of cell growth and differentiation. Irreversible damage to DNA of genes involved in regulation of growth and differentiation like tumour suppressor gene, proto-oncogenes and transcription factors may ultimately lead to cancer. Retinoids reverse potentially malignant lesions and inhibit the development of second primary cancers in patients with head and neck cancer [20].

Polymorphic genes encoding glutathione S-transferase (GST) class of enzymes, involved in detoxification of tobacco carcinogens have been implicated in increased susceptibility to lung cancer among smokers [21]. Buch et al. [22] showed that there is clear association between bidi/cigarette smoking and the development of cancer in buccal mucosa and identify the GSTM1 null genotype as a risk factor for oral cancer development in tobacco habitués of Indian origin.

Presently many novel methods are being used and proposed for the early diagnosis of cancer leading to immediate and effective treatment, e.g., Tight junction protein Claudins are abnormally regulated in several human cancers especially claudin-3 and claudin-4 [23]. SLC39A6 protein a member of a new subfamily of zinc transporters, is involved in maintaining the intracellular homeostasis of zinc, an ion that is essential in the control of gene transcription, differentiation, development and growth, suggesting that its altered distribution might promote tumorigenesis and targeting SLC39A6 might be a potential therapeutic strategy [24]. The Transient Receptor Potential (TRP) channels family which consists of seven different subfamilies, namely TRPC (Canonical), TRPV (Vanilloid), TRPM (Melastatin), TRPML (Mucolipin), TRPP (Polycystin), and TRPA (Ankyrin transmembrane protein) and TRPN (NomPC-like), are related to several physiological and pathological processes. Recent years have witnessed an increased interest of research into the connection between TRP channels and cancer, leading to the discovery of tumor-related functions such as regulation of proliferation, differentiation, apoptotis, angiogenesis, migration and invasion during cancer progression. TRP proteins can be valuable diagnostic and/or prognostic markers, as well as targets for pharmaceutical intervention and targeting [25].

\section{Cessation and De-addiction}

Since smoking is the major cause of deaths globally, one of the strategies should be focussed on making people aware and motivate them to stop or avoid it, altogether. Smoking cessation intervention includes cold turkey, self helping, identify the smoking triggers and offer ways to avoid them, nicotine replacement therapy and use of Bupropion (an antidepressant). Self-helping intervention uses materials, such as manuals, computer generated written feedback, and audio-video tapes, televised programs and behavioural intervention, help to identify smoking trigger (consumption of alcohol or finishing a meal), stressor social events and offer ways to avoid them. Nicotine replacement therapies include nicotine gum, nicotine transdermal patch, nicotine nasal spray and the nicotine inhaler. The preferred cessation approach appears to be a combination of therapies rather than use of a single intervention. Combined approach consisting of nicotine replacement therapy, providing support and skill training (to improve coping mechanisms), is the most effective means of achieving the desired goals-smoking cessation and maintenance [26].

Second approach to tobacco de-addiction is through hypnotherapy. It includes hypnosis, (an altered state of 
consciousness) in which there is heightened suggestibility which is instrumental in creating desired impact on mind of the patient, when appropriate suggestions are given [27]. In addition reflexology is also being practiced by some which is a non-conventional medical system of studying human body through the corresponding reflex areas which are located on the extremities of our body, viz., on the ears, hands and feet. It involves the external stimulation on the reflex areas for diagnostic, preventive and therapeutic purpose. It provides an alternate and non-evasive route for management of addiction [28]. Preliminary studies on Sudershan Kriya and Yoga also show promising results. These techniques help smokers to get rid of negative emotions and thoughts, increase their confidence, and make their mind calm and relaxed, and hence reduce their urge for tobacco. The regular practice may help the tobacco consumer in quitting tobacco and combating ailments caused by it [29].

\section{Conclusion}

Tobacco is a slow but sure killer. The WHO slogan in the new millennium is "Tobacco Kills, Don't Be Duped". It is predicted that the global death rate will increase up to 10 million annually in the year 2020, of which $70 \%$ will be in developing countries. Diseases related to tobacco, e.g., oral pre-cancer and cancer pose a major health challenge for $21^{\text {st }}$ century, due to rise in the incidence of smoking worldwide. Most lung cancer, emphysema and a high percentage of heart attacks are caused by cigarette smoking. Recent scientific data reveal that the cancer risk from smoking is not limited to cancer of the lung, but bladder, cervical, oesophageal, and pancreatic cancers are also caused by smoking.

A comprehensive approach is required for combating the tobacco menace. However awareness of the hazard of tobacco usage is being created in the Indian population through different media which promote the prevention as the best solution. Intense efforts are also needed towards tobacco cessation programmes. In the year 2011, Indian Health Ministry banned gutkha (crushed areca nut with tobacco) and it has been observed that this imposition has led to significant quitting among the users. In a survey, $66 \%$ quitters said that they quit because the product is banned. Behavioural therapy based prevention and cessation programmes show considerable promise for curbing tobacco epidemic. These alternatives reduce stress, calm the nerve, and give pleasure and peace of mind that induces the tobacco habitués to quit the habit.

In conclusion, considering overall high prevalence, significant mortality, morbidity and huge burden of health cost due to tobacco use in India, there is a need to develop inter-sectoral, evidence based, culturally acceptable cost effective interventions for control of smoking and smokeless tobacco use. Effective tobacco control strategies need to be based on inter-sectoral approach with various ministries, health departments, public health institutions, civil society groups, NGOs, etc. Tobacco control initiatives can be more successful if integrated with National Health Programmes and National Rural Health Mission. There should be strict enforcement of laws to prevent minors from accessing tobacco products. There should be planning and formulation of supply reduction strategies for tobacco like promoting alternate crops to tobacco.

Raising taxes on all forms of tobacco will definitely reduce the affordability and discourage current tobacco users from continuing use. Health warnings on tobacco packages are not intense enough to create their impact, as people have become habitual to see them. There is strong need to spread awareness of the health hazards, therefore family members along with medical health professionals should be sensitized and trained to help the smokers quit their habits.

Nonetheless, active tobacco cessation services in the form of tobacco cessation centres under both government and private sectors, policy planning, health education programmes, media messages and other interventions need to be directed, not only against smoking but a renewed focus needs to be directed towards equally harmful but socially more accepted smokeless tobacco products which are more commonly used as compared to smoking. 


\section{References}

1 Motherby G (1791) Medical Dictionary, Johnson, London.

2 Mayne RG (1860) An expository lexicon of the terms, ancient and modern, in medical and general science, Churchill, London.

3 Wateson $\mathrm{G}$ (1598) The cures of the diseased in forraine attempts of the English nation, London.

4 Hoffmann D, Hoffmann I (1998) Letters to the editor, tobacco smoke components. Beitrage zur Tabaksforsch International 18: 49-52.

5 Borgerding M, Klus H (2005) Analysis of complex mixtures--cigarette smoke. Exp Toxicol Pathol 57 Suppl 1: 43-73.

6 Thielen A, Klus $H$, Müller L (2008) Tobacco smoke: unraveling a controversial subject. Exp Toxicol Pathol 60: 141-156.

7 Ezzati M, Lopez AD (2003) Estimates of global mortality attributable to smoking in 2000. Lancet 362: 847-852.

8 Fowles J, Dybing E (2003) Application of toxicological risk assessment principles to the chemical constituents of cigarette smoke. Tob Control 12: 424-430.

9 Murray CJ, Lopez AD (1996) The Global Burden of Disease: A comprehensive assessment of mortality and disability from diseases, injuries and risk factors in 1990 and projected to 2020. Harvard School of Public Health, Cambridge, Massachussets.

10 Jindal SK, Aggarwal AN, Chaudhry K, Chhabra SK, D'Souza GA, et al. (2006). Tobacco smoking in India: Prevalence, quit-rates and respiratory morbidity. The Indian Journal of Chest Diseases and Allied Sciences, 48: 37-42.

11 John RM (2005) Tobacco consumption patterns and its health implications in India. Health Policy 71: 213-222.

12 Gupta V, Yadav K, Anand K (2010) Patterns of tobacco use across rural, urban, and urban-slum populations in a north Indian community. Indian J Community Med 35: 245-251.

13 GATS (2010) Tobacco use: India Report 2009-2010, Ministry of Health and Family Welfare, Government of India 1-36.

14 Muller PA, Vousden KH (2014) Mutant p53 in cancer: new functions and therapeutic opportunities. Cancer Cell 25: 304-317.

15 Heinzel PA, Balaram P, Bernard HU (1996) Mutations and polymorphisms in the p53, p21 and p16 genes in oral carcinomas of Indian betel quid chewers. Int J Cancer 68: 420-423.

16 Kononen J, Bubendorf L, Kallioniemi A, Bärlund M, Schraml P, et al. (1998) Tissue microarrays for high-throughput molecular profiling of tumor specimens. Nat Med 4: 844-847.

17 Bagadi SAR, Rahlan R (2002) Tobacco genetic susceptibility and breast cancer, Proceedings of World Assembly on Tobacco Counters Health 2: 245-248.

18 Rahlan R, Khanna R, Soni S, Chakravarti N, Kaur J, et al. (2000) Gene chips: A step forward in understanding tobacco associated oral cancer, Proceedings of World Assembly on Tobacco Counters Health 1: 129-133.

19 Lippman SM, Benner SE, Hong WK (1994) Cancer chemoprevention. J Clin Oncol 12: 851-873.

20 Chakravarti N, Mathur M, Bahadur S, Rahlan R (2000) Tobacco abused oral precancerous lesions: Plausible targets for chemoprevention. Proceedings of World Assembly on Tobacco Counters Health 1: 139-143.

21 Zhong S, Howie AF, Keterrer B, Taylor J, Hayes JD, et al. (1991) Glutathione S-transferase mu locus: use of genotyping and phenotyping assays to assess association with lung cancer susceptibility. Carcinogenesis 12: 1533-1537.

22 Buch SC, Fakih AR, Bhisey RA (2000) Glutathione S-transferase genotypes and individual susceptibility to oral cancer. Proceedings of World Assembly on Tobacco Counters Health 1: 152-155.

23 Morin PJ (2005) Claudin proteins in human cancer: promising new targets for diagnosis and therapy. Cancer Res 65: 9603-9606.

24 Cui XB, Shen YY, Jin TT, et al. (2015) SLC39A6: a potential target for diagnosis and therapy of esophageal carcinoma. J Transl Med 13: 321.

25 Santoni G, Farfariello V (2011) TRP channels and cancer: new targets for diagnosis and chemotherapy. Endocr Metab Immune Disord Drug Targets 11: 54-67.

26 Golizadeh L (2002) Assessment of smoking cessation intervention in hospitalized cardiac patients in Sahid Madani centre of medical and educational in April 2002. Proceedings of World Assembly on Tobacco Counters Health 2: 188-190.

27 Kaushik RM, Kaushik R (2002) Role of hypnotherapy in de-addiction from tobacco. Proceedings of World Assembly on Tobacco Counters Health 2: 208-213.

28 Dalal K (2002) Role of reflexology in de-addiction. Proceedings of World Assembly on Tobacco Counters Health 2: 214-220.

29 Kumar A, Rahlan R, Kochupillai V (2002) Quitting tobacco through Sudarshan Kriya Yoga. Proceedings of World Assembly on Tobacco Counters Health 2: 221-223.

30 Russell MA (1990) The nicotine addiction trap: a 40-year sentence for four cigarettes. Br J Addict 85: 293-300.

31 DiFranza JR, Savageau JA, Fletcher K, Ockene JK, Rigotti NA, et al. (2002) Measuring the loss of autonomy over nicotine use in adolescents: the DANDY (Development and Assessment of Nicotine Dependence in Youths) study. Arch Pediatr Adolesc Med 156: 397-403.

32 Caumo W, Schmidt AP, Schneider CN, Bergmann J, Iwamoto CW, et al. (2001) Risk factors for preoperative anxiety in adults. Acta Anaesthesiol Scand 45: 298-307.

33 Dagher A, Bleicher C, Aston JA, Gunn RN, Clarke PB, et al. (2001) Reduced dopamine D1 receptor binding in the ventral striatum of cigarette smokers. Synapse 42: 48-53.

34 Di Chiara G, Acquas E, Carboni E (1992) Drug motivation and abuse: a neurobiological perspective. Ann N Y Acad Sci 654: 207-219.

35 Gamberino WC, Gold MS (1999) Neurobiology of tobacco smoking and other addictive disorders. Psychiatr Clin North Am 22: 301-312.

36 Shadel WG, Shiffman S, Niaura R, Nichter M, Abrams DB (2000) Current models of nicotine dependence: What is known and what is needed to advance understanding of tobacco etiology among youth. Drug and Alcohol Dependence 59: S9-S21.

37 Takeyama K, Jung B, Shim JJ, Burgel PR, Dao-Pick T, et al. (2001) Activation of epidermal growth factor receptors is responsible for mucin synthesis induced by cigarette smoke. American Journal of Physiology: Lung Cellular and Molecular Physiology 280: L165-L172.

38 Mitchell BE, Sobel HL, Alexander MH (1999) The adverse health effects of tobacco and tobacco-related products. Prim Care 26: 463-498.

39 Barua RS, Ambrose JA, Reynolds LJE, DeVoe MC, Zervas JG, et al. (2002) Heavy and light cigarette smokers have similar dysfunction of endothelial vasoregulatory activity: an in vivo and in vitro correlation. Journal of the American College of Cardiology 39: 1758-1763. 
40 Tsuchiya M, Asada A, Kasahara E, Sato EF, Shindo M, et al. (2002) Smoking a single cigarette rapidly reduces combined concentrations of nitrate and nitrite and concentrations of antioxidants in plasma. Circulation 105: 1155-1157.

41 Brodish PH (1998) The Irreversible Health Effects of Cigarette Smoking. The American Council on Science and Health, USA.

42 Rose JE, Behm FM, Westman EC (2001) Acute effects of nicotine and mecamylamine on tobacco withdrawal symptoms, cigarette reward and ad lib smoking. Pharmacol Biochem Behav 68: 187-197.

43 Pickworth WB, Moolchan ET, Berlin I, Murty R (2002) Sensory and physiologic effects of menthol and non-menthol cigarettes with differing nicotine delivery. Pharmacol Biochem Behav 71: 55-61.

44 Primatesta P, Falaschetti E, Gupta S, Marmot MG, Poulter NR (2001) Association between smoking and blood pressure: evidence from the health survey for England. Hypertension 37: 187-193.

45 Righetti M, Sessa A (2001) Cigarette smoking and kidney involvement. J Nephrol 14: 3-6.

46 Codandabany U (2000) Erythrocyte lipid peroxidation and antioxidants in cigarette smokers. Cell Biochem Funct 18: 99-102.

47 Cafolla A, Dragoni F, Girelli G, Tosti ME, Costante A, et al. (2000) Folate status in Italian blood donors: relation to gender and smoking. Haematologica 85: 694-698.

48 Fitzpatrick TM, Blair EA (2000) Upper airway complications of smoking. Clin Chest Med 21: 147-157, x.

49 Smit CF, Copper MP, van Leeuwen JA, Schoots IG, Stanojcic LD (2001) Effect of cigarette smoking on gastropharyngeal and gastroesophageal reflux. Ann Otol Rhinol Laryngol 110: 190-193.

50 Falk GW (2002) Barrett's esophagus. Gastroenterology 122: 15691591.

51 Coroll AH (1995) Primary Care Medicine. Lippincott, Phillidelphia.

52 Ma L, Wang WP, Chow JY, Lam SK, Cho CH (2000) The role of polyamines in gastric mucus synthesis inhibited by cigarette smoke or its extract. Gut 47: 170-177.
53 Goldman L (2000) Cecil Textbook of Medicine. The American psychiatric publishing Textbook of psychosomatic medine, USA.

54 Fredriksson M, Bergström K, Asman B (2002) IL-8 and TNF-alpha from peripheral neutrophils and acute-phase proteins in periodontitis. J Clin Periodontol 29: 123-128.

55 Johnson GK, Slach NA (2001) Impact of tobacco use on periodontal status. J Dent Educ 65: 313-321.

56 Katz PO (1998) Gastro-oesophageal Reflux Disease. Journal of the American Geriatrics Society 46: 1558-1565.

57 Nagler R, Lischinsky S, Diamond E, Drigues N, Klein I, et al. (2000) Effect of cigarette smoke on salivary proteins and enzyme activities. Arch Biochem Biophys 379: 229-236.

58 Nagler RM, Lischinsky S, Diamond E, Klein I, Reznick AZ (2001) New insights into salivary lactate dehydrogenase of human subjects. J Lab Clin Med 137: 363-369.

59 Nagler RM, Klein I, Zarzhevsky N, Drigues N, Reznick AZ (2002) Characterization of the differentiated antioxidant profile of human saliva. Free Radic Biol Med 32: 268-277.

60 Zappacosta B, Persichilli S, Mordente A, Minucci A, Lazzaro D, et al. (2002) Inhibition of salivary enzymes by cigarette smoke and the protective role of glutathione. Hum Exp Toxicol 21: 7-11.

61 Agius AM, Wake M, Pahor AL, Smallman LA (1995) Smoking and middle ear ciliary beat frequency in otitis media with effusion. Acta Otolaryngol 115: 44-49.

62 Lieu JE, Feinstein AR (2000) Confirmations and surprises in the association of tobacco use with sinusitis. Arch Otolaryngol Head Neck Surg 126: 940-946.

63 Behrman RE (2000) Nelson Textbook of Pediatrics. WB Saunders Company, USA.

64 Lasley MV, Shapiro GG (1999) Pediatric allergy and immunology: Rhinitis and sinusitis in children. Immunology and Allergy Clinics of North America 19: 437 pp.

65 Sharma KK (1992) Marginal growth on India's cigarette market, World Tobacco. 